\title{
Seasonal and inter-annual variability in bacterial production and biomass in a temperate estuary
}

\author{
Matthew P. Hoch *, David L. Kirchman \\ College of Marine Studies, University of Delaware, Lewes, Delaware 19958, USA
}

\begin{abstract}
Dynamics of heterotrophic bacteria and phytoplankton in the Delaware Estuary (USA) were studied over $3 \mathrm{yr}$ along a sampling transect that encompassed the entire salinity gradient $(0$ to $32 \%)$. Bacterial abundance and chlorophyll a concentration were only weakly correlated $(\mathrm{r}=0.17)$. Areal bacterial production (from ${ }^{3} \mathrm{H}$-thymidine and ${ }^{14} \mathrm{C}$-leucine incorporation rates) covaried with phytoplankton production in all geographic regions of the estuary $(r=0.70)$, although phytoplankton production explained less of the variance in bacterial production upstream ( $<7 \%$ salinity) than in the middle and lower estuary. Specific growth rate correlated with temperature when waters were $<12^{\circ} \mathrm{C}$, but there was no relationship at higher temperatures $\left(>12^{\circ} \mathrm{C}\right)$. Over the entire estuary, the ratio of annual bacterial production to phytoplankton production was 0.4 . In contrast, in the upper estuary bacterial production exceeded phytoplankton production by 1.4 -fold, suggesting that allochthonous sources of organic matter are more important than phytoplankton in supporting bacterial growth in this region. During 5 yr of study, the summer average (May to September) of bacterial abundance and production varied 2 -fold, which could largely be explained by the summer phytoplankton production. Even though bacteria and phytoplankton are uncoupled during the change of seasons, year-to-year variation in bacteria is apparently controlled by primary production and the fraction of primary production processed by heterotrophic bacteria is relatively constant.
\end{abstract}

\section{INTRODUCTION}

Bacterial biomass and production often covary with that of phytoplankton, such as in depth profiles, along horizontal transects from eutrophic coastal waters to more oligotrophic open oceans (Fuhrman et al. 1980), and in cross-ecosystem comparisons (Cole et al. 1988, Ducklow \& Carlson 1992). The coupling between phytoplankton and bacteria over the monthly or seasonal scale, however, is more complex, and frequently bacteria do not covary with phytoplankton. During a North Atlantic spring bloom, for example, Ducklow et al. (1993) found that bacterial biomass and production lagged a few weeks behind increases in phytoplankton production and biomass. Simon \& Tilzer (1987) observed, on the other hand, that bacteria and phytoplankton generally covaried during a year-long study of Lake Constance (W. Europe) whereas Nagata (1987) found negative correlations between bacterial and

\footnotetext{
- Present address: Texas A\&M University, c/o U.S. EPAGBERL, Gulf Breeze, Florida 32561, USA
}

phytoplankton parameters in Lake Biwa (Japan). Few investigators have examined both bacteria and phytoplankton during an entire year, much less over several years, in a marine system. In a year-long study of an estuary, Wright et al. (1987) did not find any correlation between bacterial abundance and chlorophyll. Ducklow \& Shiah (1993), who give only a few results of their extensive studies, report low covariation between bacterial and phytoplankton parameters in the Chesapeake Bay (USA) during 1984-1989.

The seasonal and inter-annual variation in bacterial parameters, especially compared with analogous phytoplankton parameters, is essential to understand because bacteria are an important component of aquatic ecosystems due to their high biomass and consumption of primary production (Cole et al, 1988, Ducklow \& Carlson 1992). In addition, careful analysis of this variation may reveal insights into what controls bacterial production. Several factors have been identified. Topdown control, i.e. grazing by flagellates and other organisms, is thought to set limits on bacterial abundance and biomass (Wright 1988, Billen et al. 1990). 
Bacterial growth rates, on the other hand, are set by 'bottom-up' factors. Although inorganic nutrients can affect bacterial growth, a good example being phosphate in lakes (Toolan et al. 1991, Morris \& Lewis 1992), the 2 most important bottom-up factors are probably temperature and the supply of dissolved organic matter (DOM). The relative importance of these 2 factors is not well understood.

Coffin \& Sharp (1987) sampled over large spatial and temporal scales during early spring to summer 1985 and began to characterize the roles of phytoplankton, microflagellates and temperature in regulating bacterial abundance and production in the Delaware Estuary (USA). We extended this study by measuring bacterial parameters from April 1986 to September 1988, which allows us to analyze factors controlling bacterial parameters (especially temperature and primary production) more thoroughly than could be done by Coffin \& Sharp (1987). These additional years also allow us to examine inter-annual variability in both bacterial and phytoplankton parameters. We found that temperature was most important in explaining bacterial production for the upper estuary where bacterial production exceeded phytoplankton production. At the mouth of the estuary during spring and summer, however, DOM supply regulated bacterial production both seasonally and inter-annually.

\section{MATERIALS AND METHODS}

Field sampling and routine analyses. The Delaware Estuary was sampled 23 times during April 1986 to September 1988. For inter-annual comparisons, unpublished data from 3 cruises during summer 1990 were included. The transect began north of Wilmington, Delaware, and followed the spine of the estuary to the mouth of the bay (Fig. 1). On each cruise, surface water was collected from RV 'Cape Henlopen' at 7 to 13 stations located along this transect. We used a sampling rosette with 101 Niskin bottles and a Neil-Brown IIIb CTD system for the measurement of conductivity, temperature, and depth

Dissolved primary amines (DPA) were assayed by the o-phthalaldehyde (OPA) method (Parsons et al. 1984) with glycine used as a standard. Fluorescence due to $\mathrm{NH}_{4}{ }^{+}$was subtracted from total fluorescence based on OPA- $\mathrm{NH}_{4}{ }^{+}$fluorescence measured in pure $\mathrm{NH}_{4}{ }^{+}$solutions and ambient $\mathrm{NH}_{4}{ }^{+}$concentration. The $\mathrm{NH}_{4}^{+}$ method is described by Sharp et al. (1982). Primary productivity $\left({ }^{14} \mathrm{CO}_{2}\right.$ uptake) and chlorophyll a (chl a) were measured as described by Pennock \& Sharp (1986) and Sharp et al. (1982), respectively. Photosyntheticallyavailable radiation was measured with a QSR-250 integrating quantum meter. Bacterial abundance in

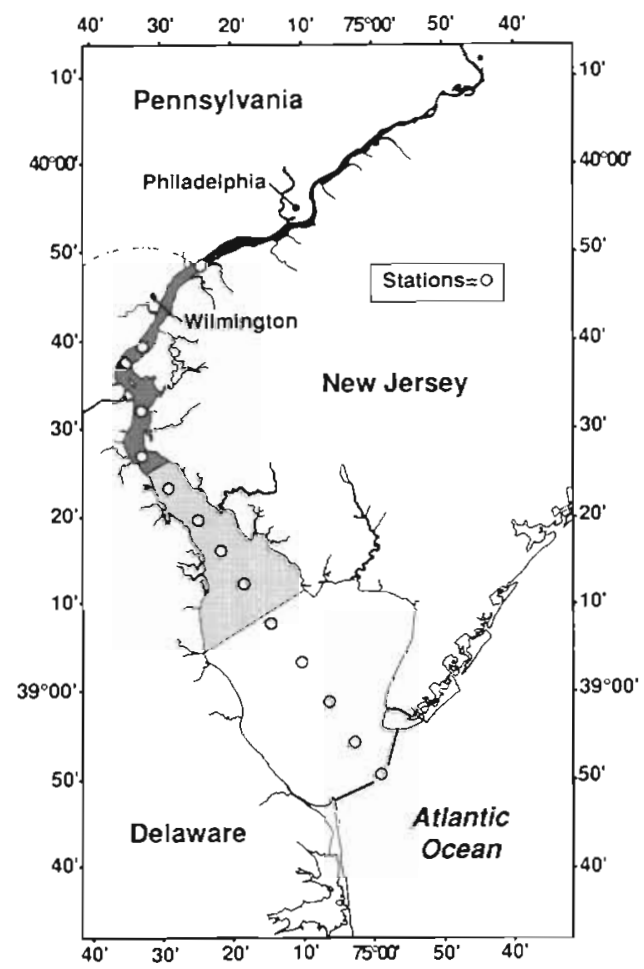

Fig. 1. The Delaware Estuary, divided into 3 geographic regions: upper (upper 5 stations), middle (middle 4 stations), lower (lower 5 stations)

fixed ( $2 \%$ formalin) samples was determined by acridine orange direct counts (Hobbie et al. 1977).

Bacterial production. Bacterial production was estimated from DNA and protein synthesis based on incorporation rates of thymidine (TdR; Fuhrman \& Azam 1982) and leucine (Leu; Kirchman et al. 1985) respectively. Details of the methods used from April 1986 through 1987 are described in Kirchman \& Hoch (1988). In 1988, $\left[{ }^{3} \mathrm{H}\right] \mathrm{TdR}$ (specific activity of $>70 \mu \mathrm{Ci}$ $\mathrm{nmol}^{-1}$ ) and $\left[{ }^{14} \mathrm{C}\right.$ Leu (specific activity of $0.3 \mu \mathrm{Ci}$ $\mathrm{nmol}^{-1}$ ) were added together to $10 \mathrm{ml}$ of seawater at final concentrations of 10 and $20 \mathrm{nM}$, respectively (Chin-Leo \& Kirchman 1988). Incubations were run in triplicate, plus a formalin-killed control, and in the dark for 15 to $45 \mathrm{~min}$ at the in situ temperature. Incubations were stopped by addition of ice-cold $5 \%$ trichloracetic acid (TCA). Samples were filtered onto $0.45 \mu \mathrm{m}$ Millipore HA filters and then rinsed with $3 \mathrm{ml}$ ice-cold $5 \%$ TCA. The filters were radioassayed by scintillation spectrometry using a dual label program for ${ }^{14} \mathrm{C}$ and ${ }^{3} \mathrm{H}$ (Beckman).

Conversion factors for estimating cell production from rates of TdR and Leu incorporated were empirically derived from dilution culture experiments by following changes in cell abundance and uptake rates (Kirchman et al. 1982). All experiments used seawater from the mouth of the bay (Fig. 1). Briefly, filtrate from 
$1 \mu \mathrm{m}$ polycarbonate filters (Nuclepore) was diluted $1: 10$ with $0.22 \mu \mathrm{m}$ filtrate and incubated in the dark at surface water temperature. The culture was subsampled about every $5 \mathrm{~h}$ over $40 \mathrm{~h}$ for determination of cell abundance and incorporation rates of $T d R$ and Leu.

The derivative (Kirchman et al. 1982) and integrative (Riemann et al. 1987) algorithms were used to calculate conversion factors from increases in cell abundance and the incorporation rates of $\left[{ }^{3} \mathrm{H}\right]$ thymidine (TdR) and $\left[{ }^{14} \mathrm{C}\right.$ leucine (Leu) (Hoch 1992, Kirchman \& Hoch 1988). Mean conversion factors calculated by the 2 algorithms did not differ $(p>0.05)$. The mean $( \pm S D)$ for the derivative method was $1.1 \pm 0.37 \times 10^{18}$ cells $\mathrm{mol}^{-1}$ and $6.5 \pm 2.0 \times 10^{16} \mathrm{cells} \mathrm{mol}^{-1}(\mathrm{n}=8)$ for TdR and Leu respectively (Hoch 1992), which do not differ significantly from the factors used by Kirchman \& Hoch (1988). Also, conversion factors calculated with the 'modified derivative' method of Ducklow et al. (1992) were similar.

Growth rates were calculated by dividing production estimates by cell abundance. Cell production was converted to carbon by assuming $20 \mathrm{fg} \mathrm{C}^{\mathrm{C}} \mathrm{cell}^{-1}$, which was the mean for biovolumes ranging from 0.036 to $0.073 \mu \mathrm{m}^{3}$ (Lee \& Fuhrman 1987). The mean bacterial volume for all seasons and locations in the Delaware Estuary was within this range (Coffin \& Sharp 1987). Areal bacterial production (mmol $\mathrm{C} \mathrm{m}^{-2} \mathrm{~d}^{-1}$ ) was calculated by multiplying the volumetric production rate $\left(\mu \mathrm{M} \mathrm{C} d^{-1}\right)$ at the surface by the depth of the water column. This integration with depth assumes that the entire water column is well mixed, which is the case for the Delaware Estuary during most of the year based on the low stratification index $(\Delta \mathrm{S} / \mathrm{H})$ (see 'Results' and Sharp et al. 1986).

Data processing and statistics. All statistical analyses in this study were performed with Systat (SYSTAT Inc., Evanston, IL, USA). The raw data used in these analyses are available in Lebo et al. (1990). Values for each property, except for temperature, were log-transformed prior to regression analysis so as to conform with the assumption of normally distributed variances. Normality was confirmed by inspection of normal probability plots. A Pearson's correlation matrix was run for the entire estuary data. Missing values were deleted listwise resulting in $\mathrm{n}=186$. Bonferroniadjusted probabilities were reported instead of nominal probabilities which do not reflect the number of correlations tested in the matrix. For regression analyses, missing data were eliminated in a pairwise fashion. The anti-log values obtained by regression equations for log-log graphs underestimate the true prediction, and therefore, a correction factor (CF) to adjust for this bias was calculated for all regressions (Sprugel 1983). A Model II (rather than Model I) regression was done because both variables had errors
(Sokal \& Rohlf 1981). When appropriate, errors were propagated according to Bevington (1969). Means of measured properties and regression slopes were compared using Student's t-tests.

\section{RESULTS}

\section{Physical and chemical properties of the Delaware Estuary}

The Delaware Estuary was divided into 3 regions (upper, middle, and lower estuary), the same as in previous studies of phytoplankton dynamics in this system (Fig. 1; Pennock 1985, Pennock \& Sharp 1986). Salinity was 0.04 to $13.5 \%$ in the upper, 4.4 to $21.2 \%$ in the middle, and 14.8 to $32.5 \%$ in the lower estuary. Temperature among regions only differed in the summer when surface waters were cooler by a couple of degrees $(p<0.05)$ in the lower estuary than in the middle and upper (Fig. 2A). The upper estuary was ex-
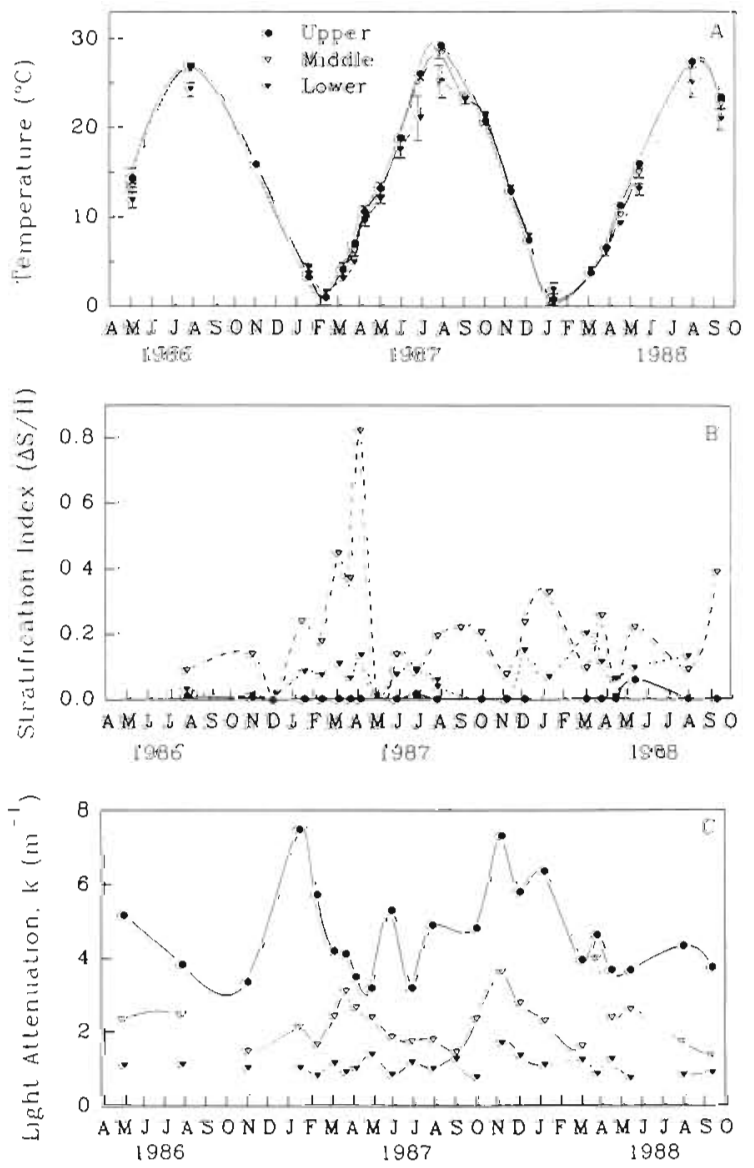

Fig. 2. (A) Temperature, (B) stratification index and (C) light attenuation in the Delaware Estuary. Each point is the mean of each region. The error bars for temperature are $1 \mathrm{SD}$, and the mean coefficient of variation ( \pm SD) for attenuation was $30+15 \%$ 
tremely well mixed $(\Delta \mathrm{S} / \mathrm{H}=0.004)$, whereas the middle and to a lesser extent the lower estuary were weakly stratified during spring (Fig. 2B). The highest mean light attenuation $\left(k=4.5 \mathrm{~m}^{-1}\right)$ was in the upper estuary at the turbidity maxima $\left(k>2.5 \mathrm{~m}^{-1}\right.$; Biggs et al. 1983) where salinity was $2.9 \pm 2.8 \%$ (mean \pm SD) (Fig. 2C). Light attenuation ( $k$ ) decreased significantly downstream $(\mathrm{p}<0.05)$. Ammonium $\left(24 \pm 23 \mu \mathrm{M}_{i} \mathrm{n}=\right.$ $107)$ and dissolved primary amine (DPA) $(1.8 \pm 1.7 \mu \mathrm{M}$; $\mathrm{n}=75$ ) (annual means $\pm \mathrm{SD}$ ) were highest $(\mathrm{p}<0.05)$ in the upper estuary; only $\mathrm{NH}_{4}{ }^{+}$concentration was significantly greater $(\mathrm{p}<0.05)$ in the middle $(8.1 \pm 9.8 \mu \mathrm{M}$; $\mathrm{n}=89)$ compared to the lower estuary $(1.9 \pm 2.3 \mu \mathrm{M}$; $\mathrm{n}=108$ ). Ammonium and DPA concentrations typically were high in fall and winter, decreased after the spring bloom, and remained low throughout the summer and early fall (not shown).

\section{TdR- versus Leu-based estimates of bacterial production}

Regression coefficients for the log-transformed bacterial production rates were calculated for the whole estuary and for each region using all data over the $3 \mathrm{yr}$ period. The slope of the log-log plot of Leu and TdR bacterial production was the same for all regions $(p>0.05)$. When corrected properly, the relationship between Leu and TdR is

$$
\begin{gathered}
\text { Leu-BP }=0.726 \mathrm{TdR}-\mathrm{BP}^{0.89} \\
\left(\mathrm{CF}=1.23 ; \mathrm{r}^{2}=0.68 ; \mathrm{n}=247 ; \mathrm{p}<0.001\right)
\end{gathered}
$$

where Leu-BP and TdR-BP are bacterial production $\left(\mu \mathrm{M} \mathrm{C} \mathrm{d}^{-1}\right)$ estimated by the Leu and TdR techniques, respectively. This relationship accounts for about $70 \%$ of the variability between the 2 techniques.

Over the 3 yr surveyed, maxima and minima in bacterial production $\left(\mu \mathrm{M} \mathrm{C} \mathrm{d}^{-1}\right)$ measured by the Leu method corresponded with those estimated by the TdR technique. However, bacterial production estimated from Leu incorporation rates was lower than that measured with the TdR technique. For example, using the equation above, if TdR-BP $=2 \mu \mathrm{M} \mathrm{Cd}^{-1}$, then Leu$\mathrm{BP}=1.4 \mu \mathrm{M} \mathrm{C} \mathrm{d}^{-1}$. The difference between Leu-BP and $\mathrm{TdR}-\mathrm{BP}$ became larger with increasing bacterial production. Nonetheless, all general relationships and comparisons with other parameters (e.g. phyto- plankton production) among geographic regions of the estuary were the same for bacterial production and growth rates based on Leu incorporation. Estimates of bacterial production presented below were based on the TdR technique using the mean conversion factor of $1.1 \times$ $10^{18} \mathrm{cell} \mathrm{mol}^{-1} \mathrm{TdR}$ which was lower than the commonly used value of $2.0 \times 10^{18}$ cell $\mathrm{mol}^{-1} \mathrm{TdR}$ (Fuhrman \& Azam 1982).

\section{Overview of relationships}

The highest correlations ( $p<0.001$ ) were between temperature and all other properties considered, except for chl a and DPA which did not covary (Table 1). Chl a also did not correlate with bacterial abundance $(p>0.05)$. Bacterial abundance and production were strongly related $(r=0.68 ; \mathrm{p}<0.001)$, and both correlated with phytoplankton production $(\mathrm{p}<0.001)$. Bacterial growth rate correlated with temperature $(p<0.001)$ and to a lesser extent with chlorophyll and phytoplankton production $(p<0.05)$. Ammonium and DPA, both potential sources of nitrogen for bacterial production (Wheeler \& Kirchman 1986), were highly correlated (Pearson $r=0.63 ; p<$ $0.0001)$. There was a negative correlation between bacterial abundance and DPA $(r=-0.34 ; \mathrm{p}<0.001)$ which suggests consumption of DPA by bacteria at the beginning of the summer. Below, some of these relationships were examined further using regression analyses.

\section{Phytoplankton biomass and production}

The spring bloom occurred in early March in the lower (Fig. 3A) and middle (Fig. 4A) estuary, with the highest biomass (40 to $65 \mu \mathrm{g} \mathrm{chl} \mathrm{a} \mathrm{l}^{-1}$ ) in the middle

Table 1. Pearson correlation (r) matrix for all data collected throughout the Delaware Estuary from 1986 to 1988 . Missing values were deleted listwise so that $n=186$. Properties included in the analysis were temperature (TEMP) and the log-transformed values for dissolved primary amines (DPA), chl a (CHL), areal primary production (Pprod), bacterial abundance (BACT), areal bacterial production (Bprod), and bacterial specific growth rate (GROT)

\begin{tabular}{|lccccccc|}
\hline & TEMP & DPA & CHL & Pprod & BACT & Bprod & GROT \\
\hline TEMP & & & & & & \\
DPA & $-0.385 \cdots$ & & & & & \\
CHL & -0.004 & 0.032 & & & & \\
Pprod & $0.467 \cdots$ & $-0.285 \cdots$ & $0.540 \cdots$ & & & \\
BACT & $0.662 \cdots$ & $-0.342 \cdots$ & 0.158 & $0.537 \cdots$ & & \\
Bprod & $0.757 \cdots$ & $-0.231 \cdot$ & $0.242 \cdot$ & $0.489 \cdots$ & $0.678 \cdots$ & \\
GROT & $0.489 \cdots$ & -0.032 & $0.279 \cdots$ & $0.229 \cdot$ & 0.101 & $0.765 \cdots$ \\
'p $0.05 ; \cdots p<0.01 ; \cdots p<0.001$ & & & & \\
\hline
\end{tabular}




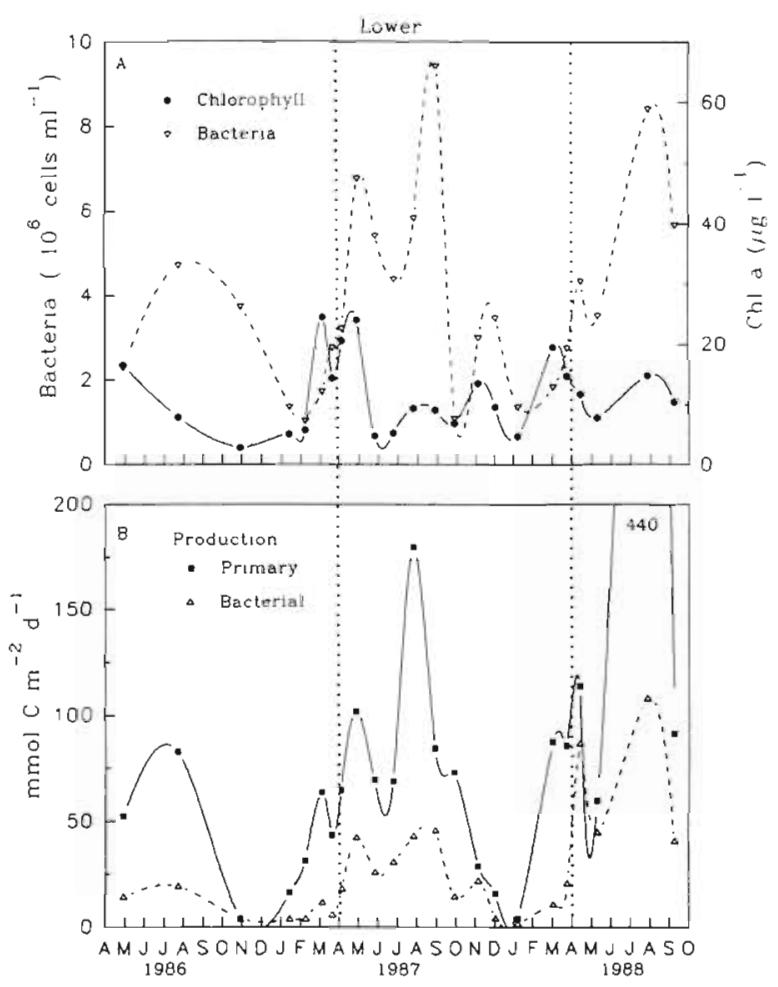

Fig. 3. (A) Bacterial abundance (mean CV $\pm \mathrm{SD} ; 15 \pm 11 \%$ ) and chl a concentration $(43 \pm 26 \%)$ and (B) bacterial (36 \pm $21 \%)$ and primary production $(42 \pm 29 \%)$, in the lower estuary. All points are regional means

estuary. Maximum spring chl a concentrations in the upper estuary (Fig. 5A) were about the same as in the lower bay ( 20 to $30 \mu \mathrm{g} \mathrm{l}^{-1}$ ). The bloom in the upper estuary during 1988 lagged behind the downstream regions. Increases in phytoplankton biomass in the Delaware Estuary were in response to both light and hydrographic conditions (Pennock 1985, Sharp et al. 1986), and therefore preceded increases in water temperature (Fig. 2). This partly accounts for the lack of correlation between chl $a$ and temperature (Table 1).

Throughout the estuary, chl a decreased to $<10 \mu \mathrm{g}$ $\mathrm{l}^{-1}$ after the large bloom in spring. In contrast, phytoplankton production remained high after the spring bloom and until late fall (Figs. 3B, 4B \& 5B). Phytoplankton production during summer 1986 was lower than the 2 following years by 20 to $80 \mathrm{mmol} \mathrm{C} \mathrm{m}^{-2} \mathrm{~d}^{-1}$, the amount depending on the geographic region. Phytoplankton production was highest in the lower estuary during late summer 1987 and 1988 (>175 mmol $\mathrm{C} \mathrm{m}{ }^{-2} \mathrm{~d}^{-1}$; Fig. 3B) despite the spring bloom being smaller in this region than in the other 2 regions. Annual means (all years together) for both chl $a$ and phytoplankton production in the upper estuary were significantly less than in the middle and lower regions $(p<0.05)$, and there was no difference between middle and lower estuary means ( $p>0.05$; Table 2 ). These general cycles in phytoplankton biomass and production were repeated each year (see also Pennock 1985. Pennock \& Sharp 1986). The inter-annual variability in phytoplankton is discussed below in greater detail.

\section{Bacterial abundance versus phytoplankton parameters}

Variation and magnitude of bacterial abundance for each region of the estuary (Figs. 3A, 4A \& 5A) were similar during the 3 yr studied (Table 2). Generally, bacterial abundance was lowest around January and did not increase until after the spring bloom in phytoplankton biomass; abundance was highest in summer around August (Figs. 3A, 4A \& 5A) even after chl a had declined following the spring bloom. In 1987 there was a small fall bloom in bacterial abundance in addition to the large spring and summer blooms that occurred in each region of the estuary. This variation in abundance could not be explained statistically by chl $a$ in the middle and lower estuary $(r=0.10 ; p>0.05$; Table 3$)$. Only

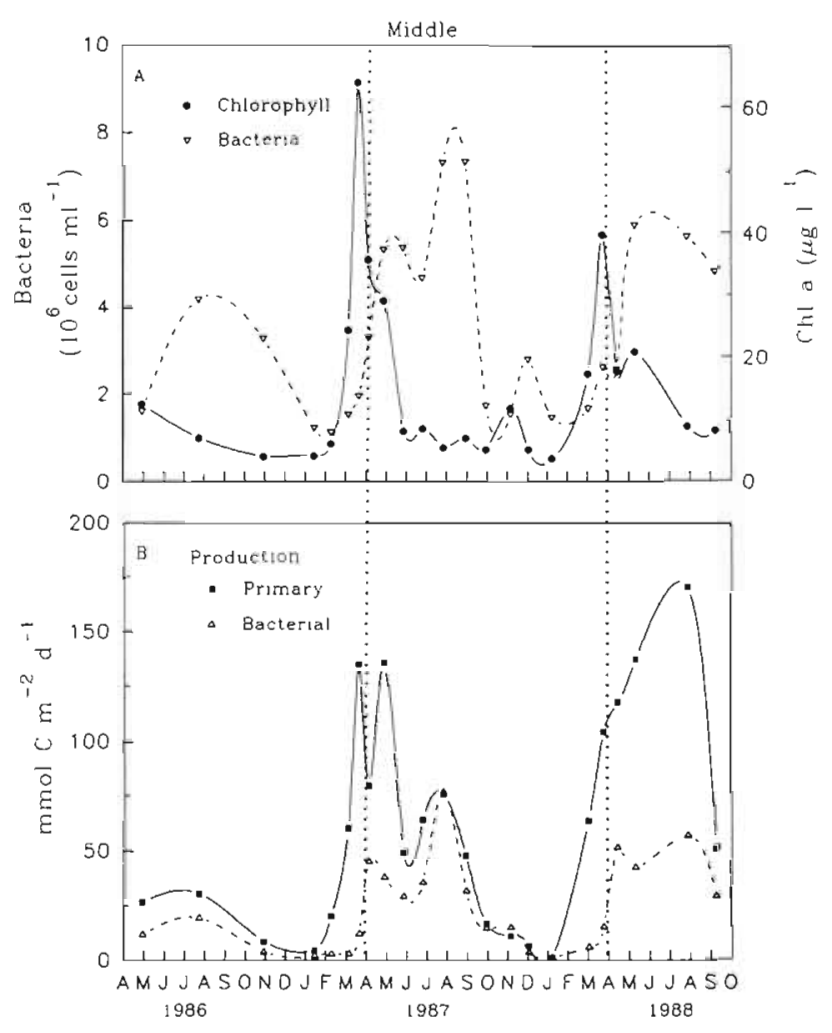

Fig. 4. (A) Bacterial abundance (mean CV \pm SD; $17 \pm 12 \%$ ) and chl a concentration $(27 \pm 15 \%)$ and $(B)$ bacterial $(24 \pm$ $15 \%)$ and primary production $(48 \pm 28 \%)$, in the middle estuary. All points are regional means 


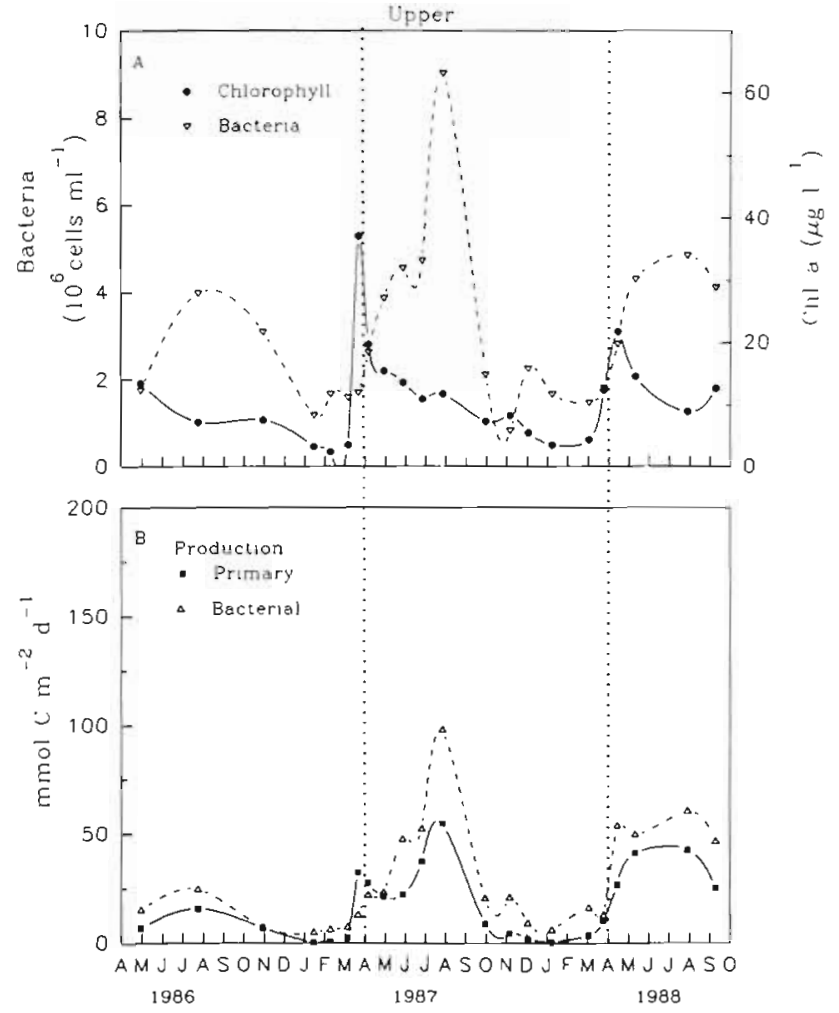

Fig. 5. (A) Bacterial abundance (mean CV $\pm \mathrm{SD} ; 18 \pm 9.7 \%$ ) and chl a concentration ( $36 \pm 20 \%$ ) and (B) bacterial (37 \pm $18 \%)$ and primary production $(59 \pm 21 \%)$, in the upper estuary. All points are regional means

$15 \%$ of the variance in bacterial abundance could be accounted for by chl a in the upper estuary (Table 3). Bacterial abundance in summer 1986 was lower than in the other 2 yr when phytoplankton production was also relatively low.
Phytoplankton production explained $44 \%$ of the variance in bacterial abundance in the upper region, but only $12 \%$ in the lower estuary (Table 3 ). These results suggest that bacterial abundance was controlled by phytoplankton interactions more at the beginning of the salinity gradient than downstream. About $40 \%$ of the variation in bacterial abundance was explained by bacterial production (Table 3). Regression slopes for bacterial production versus abundance for the 3 estuarine regions did not differ significantly $(p>0.05$; slope $=1.1 \pm 0.12$ ).

\section{Bacterial production versus phytoplankton production}

Generally, maximal bacterial production covaried with maximal phytoplankton production (Figs. 3B, 4B \& 5B). In early spring, however, bacterial production lagged after the first peak in phytoplankton production which was associated with the chl a peak. This lag, which occurred in both 1987 and 1988, was less pronounced in the upper estuary (Fig. 5B) where the phytoplankton production was significantly lower ( $p<$ 0.05; Table 2) due to light limitation (Pennock \& Sharp 1986). Also, bacterial production in the upper estuary during winter was slightly higher than in the rest of the estuary. Within each region of the estuary about $50 \%$ of the variance in bacterial production could be explained by phytoplankton production and about $45 \%$ by bacterial abundance (Table 3 ). Little of the variability in bacterial production was explained by chl a $\left(r^{2}=0.11\right)$.

Phytoplankton production in the upper region (Fig. 5B) was often less than bacterial production integrated over the water column (i.e. areal production) but

Table 2. Summary of biological properties for the upper, middle, and lower regions of the Delaware Estuary, 1986 to 1988. The ratio of bacterial production to primary production is given as Bprod : Pprod

\begin{tabular}{|c|c|c|c|c|c|c|}
\hline & \multirow{2}{*}{$\begin{array}{c}\text { Chl a } \\
\left(\mu g l^{-1}\right)\end{array}$} & \multirow{2}{*}{$\begin{array}{c}\text { Primary } \\
\text { production } \\
\left(\mathrm{mmol} \mathrm{C} \mathrm{m}^{-2} \mathrm{~d}^{-1}\right)\end{array}$} & \multicolumn{3}{|c|}{ - Bacteria } & \multirow[t]{2}{*}{ Bprod : Pprod } \\
\hline & & & $\begin{array}{l}\text { Abundance } \\
\left(10^{6} \mathrm{ml}^{-1}\right)\end{array}$ & $\begin{array}{l}\text { Growth } \\
\text { rate }\left(\mathrm{d}^{-1}\right)\end{array}$ & $\begin{array}{c}\text { Production } \\
\left(m m o l \mathrm{C} \mathrm{m}^{-2} \mathrm{~d}^{-1}\right)\end{array}$ & \\
\hline \multicolumn{7}{|l|}{ Upper region } \\
\hline $\begin{array}{l}\text { Mean } \pm \mathrm{SD} \\
\text { (Max min) }\end{array}$ & $\begin{array}{l}11.2 \pm 10.3 \\
(70.0 .1 .1)\end{array}$ & $\begin{array}{l}19.0 \pm 19.9 \\
(82.4,0.17)\end{array}$ & $\begin{array}{c}3.0 \pm 2.0 \\
(12.7,0.78)\end{array}$ & $\begin{array}{c}0.336 \pm 0.216 \\
1.32,0.048\}\end{array}$ & $\begin{array}{l}27.3 \pm 26.2 \\
(147,1.6)\end{array}$ & $\begin{array}{c}4.32 \pm 6.32 \\
(34.10,0.20)\end{array}$ \\
\hline n & 107 & 103 & 89 & 88 & 89 & 88 \\
\hline \multicolumn{7}{|l|}{ Middle region } \\
\hline $\begin{array}{l}\text { Mean } \pm S D \\
(\operatorname{Max}, \min )\end{array}$ & $\begin{array}{l}15.0 \pm 15.6 \\
(81.7 .2 .6)\end{array}$ & $\begin{array}{l}61.4 \pm 66.3 \\
(422,0.93)\end{array}$ & $\begin{array}{c}3.3 \pm 2.1 \\
(9.1,0.93)\end{array}$ & $\begin{array}{l}0.336 \pm 0.216 \\
(0.720,0.024)\end{array}$ & $\begin{array}{c}0.240 \pm 0.144 \\
(88.4,1.20)\end{array}$ & $\begin{array}{l}23.3 \pm 0.65 \\
(5.24,0.06)\end{array}$ \\
\hline $\mathrm{n}$ & 89 & 87 & 73 & 70 & 72 & 72 \\
\hline \multicolumn{7}{|l|}{ Lower region } \\
\hline $\begin{array}{r}\text { Mean } \pm S D \\
(\text { Max, min) }\end{array}$ & $\begin{array}{l}10.8 \pm 9.0 \\
(56.3,1.1)\end{array}$ & $\begin{array}{c}75.1 \pm 101.1 \\
(735,1.3)\end{array}$ & $\begin{array}{c}3.7 \pm 2.3 \\
(11.1,0.65)\end{array}$ & $\begin{array}{l}0.216 \pm 0.168 \\
(0.984,0.024)\end{array}$ & $\begin{array}{l}24.0 \pm 25.1 \\
\{138,1,11\}\end{array}$ & $\begin{array}{l}0.51 \pm 0.54 \\
(3.48,0.05)\end{array}$ \\
\hline$n$ & 108 & 103 & 90 & 85 & 82 & 77 \\
\hline
\end{tabular}


Table 3. Linear regression statistics for bacterial abundance and production as dependent variables. All values were logtransformed. Standard error (SE) for the slope and $y$-intercept (y-int.) of the regression equation are given in parentheses. Correction factors (CF) must be applied when converting predictions to arithmetic scale. Properties are bacterial abundance (BACT; cell $\times 10^{6} \mathrm{ml}^{-1}$ ), chl a $\left(\mathrm{CHLA}_{i} \mu \mathrm{g} \mathrm{l}^{-1}\right)$, and production of phytoplankton (Pprod; mmol C $\mathrm{m}^{-2} \mathrm{~d}^{-1}$ ) and bacteria (Bprod; mmol $\mathrm{C} \mathrm{m}^{-2} \mathrm{~d}^{-1}$ ). ns: not significant

\begin{tabular}{|c|c|c|c|c|c|c|c|c|c|}
\hline \multirow[t]{2}{*}{$y, x$} & \multirow[t]{2}{*}{ Region } & \multirow[t]{2}{*}{$\mathrm{n}$} & \multirow{2}{*}{$\begin{array}{l}\text { Slope } \\
( \pm \mathrm{SE})\end{array}$} & \multirow{2}{*}{$\begin{array}{l}y \text {-int. } \\
( \pm \text { SE) }\end{array}$} & \multirow[t]{2}{*}{$r^{2}$} & \multirow{2}{*}{$\begin{array}{c}\text { F-ratio } \\
\text { (p) }\end{array}$} & \multirow[t]{2}{*}{$\mathrm{CF}$} & \multicolumn{2}{|c|}{ Model II } \\
\hline & & & & & & & & Slope & $y$-int \\
\hline \multirow[t]{4}{*}{$\begin{array}{l}\text { BACT, } \\
\text { CHLA }\end{array}$} & Whole & 252 & $\begin{array}{c}0.14 \\
(0.049)\end{array}$ & $\begin{array}{c}0.31 \\
(0.049)\end{array}$ & 0.030 & $\begin{array}{c}7.85 \\
(0.005)\end{array}$ & 1.37 & 0.81 & 0.21 \\
\hline & Uррет & 89 & $\begin{array}{c}0.30 \\
(0.075)\end{array}$ & $\begin{array}{c}0.12 \\
(0.073)\end{array}$ & 0.15 & $\begin{array}{c}15.6 \\
(<0.0001)\end{array}$ & 1.16 & 0.77 & -0.31 \\
\hline & Middle & 73 & $\begin{array}{c}0.036 \\
(0.088)\end{array}$ & $\begin{array}{c}0.40 \\
(0.094)\end{array}$ & 0.002 & $\begin{array}{l}0.166 \\
\text { (ns) }\end{array}$ & 1.23 & 0.80 & -0.37 \\
\hline & Lower & 90 & $\begin{array}{c}0.088 \\
(0.092)\end{array}$ & $\begin{array}{c}0.41 \\
(0.088)\end{array}$ & 0.010 & $\begin{array}{l}0.922 \\
\text { (ns) }\end{array}$ & 1.24 & 0.88 & -0.31 \\
\hline \multirow[t]{4}{*}{$\begin{array}{c}\text { BACT, } \\
\text { Pprod }\end{array}$} & Whole & 249 & $\begin{array}{c}0.21 \\
(0.022)\end{array}$ & $\begin{array}{c}0.16 \\
(0.033)\end{array}$ & 0.26 & $\begin{array}{c}88.6 \\
(<0.0001)\end{array}$ & 1.16 & 0.41 & -0.11 \\
\hline & Upper & 88 & $\begin{array}{c}0.25 \\
(0.031)\end{array}$ & $\begin{array}{c}0.17 \\
(0.034)\end{array}$ & 0.44 & $\begin{array}{c}66.5 \\
(<0.0001)\end{array}$ & 1.11 & 0.38 & 0.05 \\
\hline & Middle & 73 & $\begin{array}{c}0.26 \\
(0.049)\end{array}$ & $\begin{array}{r}0.056 \\
(0.078)\end{array}$ & 0.28 & $\begin{array}{c}27.2 \\
(<0.0001)\end{array}$ & 1.16 & 0.49 & -0.29 \\
\hline & Lower & 88 & $\begin{array}{c}0.20 \\
(0.057)\end{array}$ & $\begin{array}{c}0.17 \\
(0.096)\end{array}$ & 0.12 & $\begin{array}{c}12.1 \\
(0.001)\end{array}$ & 1.21 & 0.57 & -0.43 \\
\hline \multirow[t]{4}{*}{$\begin{array}{c}\text { Bprod } \\
\text { BACT }\end{array}$} & Whole & 238 & $\begin{array}{c}1.04 \\
(0.082)\end{array}$ & $\begin{array}{c}0.73 \\
(0.043)\end{array}$ & 0.41 & $\begin{array}{c}162 \\
(<0.0001)\end{array}$ & 1.37 & 1.62 & 0.48 \\
\hline & Upper & 86 & $\begin{array}{c}1.02 \\
(0.13)\end{array}$ & $\begin{array}{c}0.86 \\
(0.063)\end{array}$ & 0.42 & $\begin{array}{c}60.6 \\
(<0.0001)\end{array}$ & 1.29 & 1.57 & 0.64 \\
\hline & Middle & 70 & $\begin{array}{c}1.24 \\
(0.15)\end{array}$ & $\begin{array}{c}0.58 \\
(0.081)\end{array}$ & 0.49 & $\begin{array}{c}64.7 \\
(<0.0001)\end{array}$ & 1.38 & 1.77 & 0.35 \\
\hline & Lower & 82 & $\begin{array}{c}1.03 \\
(0.13)\end{array}$ & $\begin{array}{c}0.66 \\
(0.076)\end{array}$ & 0.43 & $\begin{array}{c}60.7 \\
(<0.0001)\end{array}$ & 1.37 & 1.57 & 0.40 \\
\hline \multirow[t]{4}{*}{$\begin{array}{l}\text { Bprod, } \\
\text { Pprod }\end{array}$} & Whole & 240 & $\begin{array}{c}0.37 \\
(0.037)\end{array}$ & $\begin{array}{c}0.70 \\
(0.055)\end{array}$ & 0.30 & $\begin{array}{c}99.4 \\
(<0.0001)\end{array}$ & 1.46 & 0.68 & 0.28 \\
\hline & Upper & 88 & $\begin{array}{c}0.43 \\
(0.048)\end{array}$ & $\begin{array}{c}0.86 \\
(0.054)\end{array}$ & 0.49 & $\begin{array}{c}80.9 \\
(<0.0001)\end{array}$ & 1.27 & 0.61 & 0.69 \\
\hline & Middle & 72 & $\begin{array}{c}0.65 \\
(0.077)\end{array}$ & $\begin{array}{c}0.18 \\
(0.12)\end{array}$ & 0.50 & $\begin{array}{c}70.5 \\
(<0.0001)\end{array}$ & 1.81 & 0.92 & -0.23 \\
\hline & Lower & 80 & $\begin{array}{c}0.65 \\
(0.073)\end{array}$ & $\begin{array}{c}0.11 \\
(0.13)\end{array}$ & 0.50 & $\begin{array}{c}78.8 \\
(<0.0001)\end{array}$ & 1.31 & 0.92 & -0.33 \\
\hline
\end{tabular}

this was not the case in the middle (Fig. 4B) or lower (Fig. $3 \mathrm{~B}$ ) regions of the Delaware Estuary (Table 2). The average ratio for bacterial production to phytoplankton production for all stations during the study was $>4$ in the upper estuary (Table 2), and bacterial production during October to March often exceeded phytoplankton production by more than 10-fold. Excluding high values from winter, the average ratio of bacterial production to phytoplankton production was $1.8(\mathrm{SD}=1.5 ; \mathrm{n}=53)$ for the upper region. This ratio averaged 0.5 to 0.6 for the middle and lower regions.

Ratios of the mean annual production for bacteria and phytoplankton are a better index for examining the fraction of primary production consumed by bacteria in the estuary because it compares total integrated production for bacterial and phytoplankton production over all 3 yr. The ratio of mean annual bacterial production to mean annual phytoplankton production for the whole estuary, weighted to relative surface area for each region (upper, $10 \%$; middle, $25 \%$; lower, $65 \%$ ), was about 0.40 . Bacterial production in the upper estuary was over 1.4 times that of phytoplankton on average, although it contributed only $11 \%$ to the overall production by bacteria because of the small relative surface area of this region. Results for the upper estuary did not change when winter data were eliminated from the analysis. In the middle and lower estuary, the ratio of annual means was 0.3 to 0.4 , which do not differ significantly $(p>0.05)$. If estimates of bacterial production based on Leu incorporation rates and conver- 
Table 4. Multiple regression analysis for bacterial production (mmol $\mathrm{C} \mathrm{m}^{-2} \mathrm{~d}^{-1}$ ) as the dependent variable. All data were logtransformed except for temperature. $y$-int. and CF are defined in Table 3. Coef.: partial regression coefficients. Standardized regression coefficients (Std coef.) are given to assess the relative importance of each independent variable in predicting bacterial production. Independent variables used were bacterial abundance (BACT; cell $\times 10^{6} \mathrm{ml}^{-1}$ ), primary production (Pprod mmol $C^{\circ}$ $\mathrm{m}^{-2} \mathrm{~d}^{-1}$ ), bacterial production (Bprod; mmol $\mathrm{C} \mathrm{m}^{-2} \mathrm{~d}^{-1}$ ), and temperature (TEMP; ${ }^{\circ} \mathrm{C}$ )

\begin{tabular}{|c|c|c|c|c|c|c|c|c|c|c|}
\hline \multirow[t]{2}{*}{ Region } & \multirow[t]{2}{*}{$n$} & \multicolumn{2}{|c|}{ BACT } & \multicolumn{2}{|c|}{ Pprod } & \multicolumn{2}{|c|}{ TEMP } & \multirow{2}{*}{$\begin{array}{l}y \text {-int } \\
( \pm \text { SE })\end{array}$} & \multirow[t]{2}{*}{$r^{2}$} & \multirow[t]{2}{*}{ CF } \\
\hline & & $\begin{array}{l}\text { Coef. } \\
( \pm S E)\end{array}$ & $\begin{array}{c}\text { Std } \\
\text { coef. }\end{array}$ & $\begin{array}{l}\text { Coef. } \\
( \pm S E)\end{array}$ & $\begin{array}{c}\text { Std } \\
\text { coef. }\end{array}$ & $\begin{array}{l}\text { Coef. } \\
( \pm \text { SE) }\end{array}$ & $\begin{array}{c}\text { Std } \\
\text { coef. }\end{array}$ & & & \\
\hline Whole & 234 & $\begin{array}{c}0.41 \\
(0.10)\end{array}$ & 0.26 & $\begin{array}{c}0.16 \\
(0.036)\end{array}$ & 0.23 & $\begin{array}{c}0.022 \\
(0.003)\end{array}$ & 0.40 & $\begin{array}{c}0.50 \\
(0.049)\end{array}$ & 0.55 & 1.33 \\
\hline Upper & 84 & $\begin{array}{c}0.26 \\
(0.16)\end{array}$ & $0.17^{\circ}$ & $\begin{array}{c}0.18 \\
(0.061)\end{array}$ & 0.28 & $\begin{array}{c}0.020 \\
(0.005)\end{array}$ & 0.42 & $\begin{array}{c}0.73 \\
(0.056)\end{array}$ & 0.62 & 1.19 \\
\hline Middle & 70 & $\begin{array}{c}0.16 \\
(0.16)\end{array}$ & $0.09^{\circ}$ & $\begin{array}{c}0.46 \\
(0.062)\end{array}$ & 0.51 & $\begin{array}{r}0.028 \\
(0.005)\end{array}$ & 0.50 & $\begin{array}{l}-0.011 \\
(0.088)\end{array}$ & 0.77 & 1.16 \\
\hline Lower & 80 & $\begin{array}{c}0.56 \\
(0.13)\end{array}$ & 0.36 & $\begin{array}{c}0.46 \\
(0.067)\end{array}$ & 0.50 & $\begin{array}{c}0.009 \\
(0.005)\end{array}$ & $0.16^{\circ}$ & $\begin{array}{r}0.015 \\
(0.10)\end{array}$ & 0.68 & 1.19 \\
\hline
\end{tabular}

sion factors are used, these ratios are lower for each region of the estuary (upper, 0.75; middle, 0.20; lower, $0.17)$ as is the weighted average for the entire estuary $(0.24)$.

\section{Effect of temperature on bacterial production}

Multiple regression analysis was used to assess the relative importance of bacterial abundance, primary production and temperature in predicting bacterial production (Table 4).

Overall, temperature was the most important property for predicting bacterial production. In the upper region of the estuary, temperature explained about twice as much variation in bacterial production as did primary production; the effect of bacterial abundance was insignificant (Table 4). In the middle region of the estuary, phytoplankton production and temperature were equally important (Table 4). Temperature had

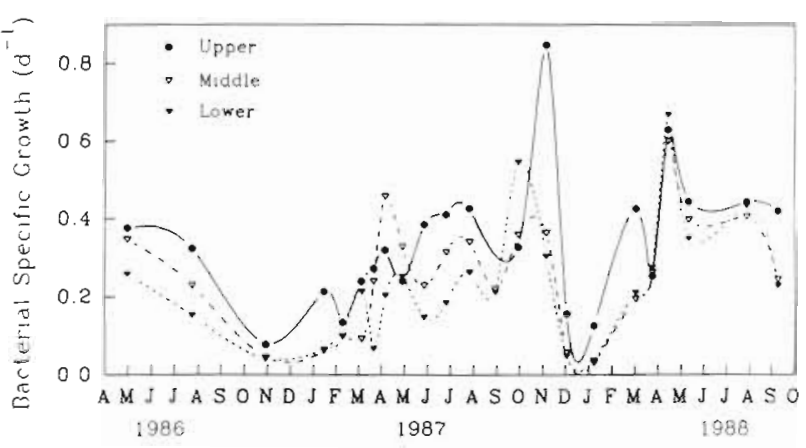

Fig. 6. Mean bacterial specific growth rate for each geographic region of Delaware Estuary. The mean coefficient of variation $(\mathrm{CV} \pm \mathrm{SD})$ for the upper, middle, and lower estuary was $37 \pm 17 \%, 27 \pm 18 \%$, and $34 \pm 23 \%$, respectively the least effect near the mouth of the bay (lower region) where phytoplankton production was the best predictor, although bacterial abundance also had a significant effect (Table 4).

\section{Effect of temperature on bacterial growth rate}

Bacterial growth rates ranged from 0.024 to $1.3 \mathrm{~d}^{-1}$ with the highest rates in the upper estuary which averaged $0.34 d^{-1}$ (Table $2 ;$ Fig. 6). Specific growth rates in the middle and lower regions did not differ significantly (ca $0.23 \mathrm{~d}^{-1} ; \mathrm{p}>0.05$ ). Maximum growth rates throughout the estuary were in fall 1987 and spring 1988 (Fig. 6).

Growth rates correlated significantly with temperature only when surface waters were $<12^{\circ} \mathrm{C}$ (i.e. November through May) (Fig. 7). In regression analysis of the upper and middle regions, temperature explained about $34 \%$ of the variation in growth rates (Table 5). There was no relationship between bacterial growth rate and temperature in warm surface water $\left(>12^{\circ} \mathrm{C}\right.$ ) when phytoplankton production was high, nor at any time in the lower estuary ( $p>0.05$ ). Temperature explained only $12 \%$ of the variation in growth rates when data for the whole estuary were used (Table 5).

The effect of temperature can also be expressed as $Q_{10}$ (the increase in growth rate for each $10^{\circ} \mathrm{C}$ increase in temperature), or more precisely the 'apparent $Q_{10}$ ' because this parameter includes variation in growth rates due to factors in addition to temperature. The apparent $Q_{10}$ for the cooler waters $\left(<12^{\circ} \mathrm{C}\right)$ was 2.9 and 1.4 for all data. Therefore it appears that temperature has a larger effect on growth rate during the cold months, particularly in middle estuary $\left(Q_{10}=5.6 ; \mathrm{r}^{2}=\right.$ 0.35; $\mathrm{p}<0.001$ ). 


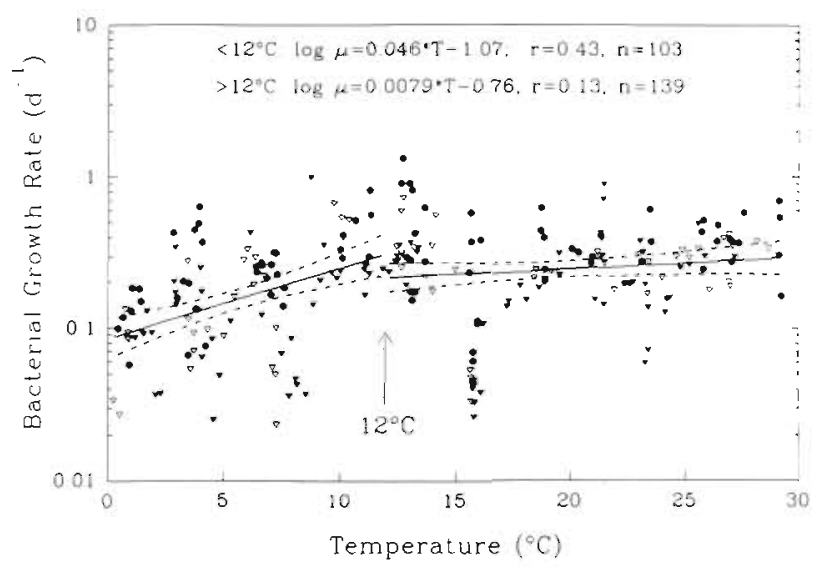

Fig. 7. Bacterial specific growth rate versus temperature for the upper $(\bullet)$, middle $(\nabla)$, and lower $(\nabla)$ estuary. Bacterial growth rates were significantly correlated with temperatures $<12^{\circ} \mathrm{C}(\mathrm{p}<0.01)$, but not at temperatures $>12^{\circ} \mathrm{C}(\mathrm{p}>0.05)$

\section{Inter-annual variability in phytoplankton and bacteria}

Inter-annual variability in production and biomass was examined by compiling data from spring and summer months from the middle and lower estuary (May through September) where we have the most data (Fig. 8). Data collected during these months in 1985 (Coffin \& Sharp 1987) and 1990 (Hoch 1992) were also included. Phytoplankton production during warm months varied from about $40 \mathrm{mmol} \mathrm{C} \mathrm{m}^{-2} \mathrm{~d}^{-1}$ in 1986 to maxima in 1985 and 1988 of roughly

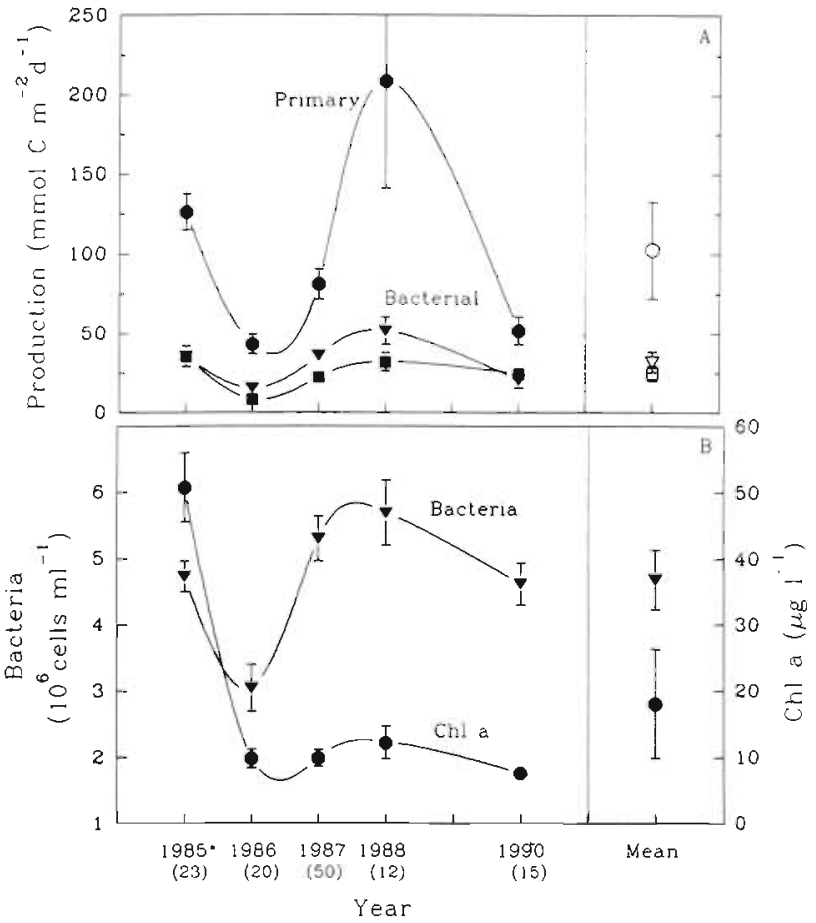

Fig. 8. (A) Mean ( \pm SE) areal bacterial and primary production, and (B) bacteria abundance and chl $a$, in the Delaware Estuary during May through September. Only data collected from the mouth of the estuary to $75 \mathrm{~km}$ upstream were used. Bacterial production was estimated from both thymidine (TdR; triangles) and leucine (Leu; squares) incorporation rates. Number of samples is in parentheses. *Data for 1985 came from Coffin \& Sharp (1987), which were adjusted for bacterial production integrated over a $13 \mathrm{~m}$, rather than a $7 \mathrm{~m}$, water column
Table 5. Linear regression statistics for log-transformed growth rate of bacteria $\left(\mathrm{d}^{-1}\right)$ versus temperature. $y$-int. and $\mathrm{CF}$ are defined in Table $3 . Q_{10}$ is the increase in growth rate for a $10^{\circ} \mathrm{C}$ increase in temperature. Regressions used to calculate the reported $Q_{10}$ values were significant $(\mathrm{p}<0.01)$ and the other analyses were not significant (ns)

\begin{tabular}{|c|c|c|c|c|c|c|}
\hline Region & $\begin{array}{c}\text { Temp } \\
\text { range }\left({ }^{\circ} \mathrm{C}\right)\end{array}$ & $\mathrm{n}$ & $\begin{array}{l}\text { Slope } \\
( \pm \text { SE) }\end{array}$ & $\begin{array}{l}y \text {-int. } \\
( \pm \mathrm{SE})\end{array}$ & $r^{2}$ & $Q_{10}$ \\
\hline Whole & All ${ }^{\circ}$ & 242 & $\begin{array}{c}0.015 \\
(0.003)\end{array}$ & $\begin{array}{c}-0.90 \\
(0.33)\end{array}$ & 0.12 & 1.41 \\
\hline Whole & $>12^{b}$ & 139 & $\begin{array}{c}0.0079 \\
(0.0051)\end{array}$ & $\begin{array}{l}-0.76 \\
(0.32)\end{array}$ & 0.02 & ns \\
\hline Whole & $<12$ & 103 & $\begin{array}{c}0.046 \\
(0.010)\end{array}$ & $\begin{array}{l}-1.07 \\
(0.33)\end{array}$ & 0.18 & 2.90 \\
\hline Upper & $<12$ & 39 & $\begin{array}{c}0.045 \\
(0.010)\end{array}$ & $\begin{array}{c}-0.89 \\
(0.22)\end{array}$ & 0.33 & 2.79 \\
\hline Middle & $<12$ & 27 & $\begin{array}{c}0.075 \\
(0.021)\end{array}$ & $\begin{array}{l}-1.28 \\
(0.33)\end{array}$ & 0.35 & 5.62 \\
\hline Lower & $<12$ & 37 & $\begin{array}{c}0.033 \\
(0.017)\end{array}$ & $\begin{array}{l}-1.12 \\
(0.35)\end{array}$ & 0.10 & ns \\
\hline \multicolumn{7}{|c|}{$\begin{array}{l}{ }^{a} \text { Results for each geographic region were similar to one another and the } \\
\text { whole data set }(\mathrm{p}<0.01) \\
{ }^{\mathrm{b}} \text { There was no correlation when each region was considered separately }\end{array}$} \\
\hline
\end{tabular}

$150 \mathrm{mmol} \mathrm{C} \mathrm{m} \mathrm{c}^{-2}$. Bacterial production, measured by either method, covaried strongly with primary production $(\mathrm{r}=0.94 ; \mathrm{n}=5 ; \mathrm{p}<0.01)$. Like primary production, the lowest bacterial production (about $15 \mathrm{mmol} \mathrm{C} \mathrm{m}^{-2}$ $\mathrm{d}^{-1}$ ) was in 1986 while the highest rates were in 1985 and 1988 (about $50 \mathrm{mmol} \mathrm{C} \mathrm{m}^{-2} \mathrm{~d}^{-1}$ ). Because bacterial production covaried with primary production, the ratio of the 2 production estimates did not vary substantially during this 5 yr period. It ranged from $0.3(0.2$ when calculated with the Leu method) in 1985 to about 0.4 in 1990 .

Bacterial biomass (cell abundance) varied like primary production, although only the 1986 value is statistically lower than the average $5 \times 10^{6} \mathrm{ml}^{-1}$ (Fig. 8B). Likewise, chl a varied little (average of $10 \mathrm{\mu g} \mathrm{l}^{-1}$ ), except that it was high in 1985 (about $50 \mu \mathrm{gl}^{-1}$ ) (Fig. 8B). 


\section{DISCUSSION}

\section{Control of bacterial biomass, production, and growth rate}

Bacterial abundance, production, and growth rate in the Delaware Estuary are low in winter and do not increase until after the bloom in phytoplankton biomass and production in spring. The spring bloom in phytoplankton results from stratification of the middle estuary and increased light (see also Pennock 1985, Pennock \& Sharp 1986, Sharp et al. 1986). Water temperatures also begin to rise at this time. Bacteria throughout the estuary respond to the temperature increase in the early spring, lagging behind the earlier response of phytoplankton to the increased photoperiod. After the spring bloom, bacterial parameters vary in response to changes in phytoplankton production. As temperature and solar irradiance decrease in the fall, biomass and production of phytoplankton and bacteria decrease. Although there are subtle differences among the 3 regions of the estuary, this annual cycle appears to apply to the entire estuary and to all 3 yr (1986 to 1988) of this study and to 1985 (Coffin \& Sharp 1987). Inter-annual variability will be discussed below.

Although bacterial parameters and phytoplankton production were highly correlated, phytoplankton biomass (chl a) was a minor factor influencing bacterial biomass and production in the Delaware Estuary. Similarly, no relationship exists between bacterial production and chl $a$ in the Chesapeake Bay for data collected from 1984 to 1989 ( $\mathrm{r}=0.10$; Ducklow \& Shiah 1993). In contrast, chl a concentrations explained as much as $88 \%$ of the variance in bacterial abundance in a cross-ecosystem study (Bird \& Kalff 1984, Cole et al. 1988). A lack of any statistical relationship between bacterial and phytoplankton biomass has been observed in the Hudson River, New York, USA (Findlay et al. 1991), the Essex Estuary, Massachusetts, USA (Wright \& Coffin 1984), Hudson River plume (Ducklow \& Kirchman 1983), and previously in the Delaware Estuary (Coffin \& Sharp 1987). Even though there is no correlation within the Delaware itself, the annual averages for each region of the estuary fall on the cross-system regression line of Cole et al. (1988). That is, although bacterial abundance can be predicted from chl a on a broad ecosystem scale (Cole et al. 1988), bacteria and phytoplankton processes are often not correlated within an ecosystem over the seasonal time scale.

All bacterial parameters, within all regions of the Delaware Estuary, were correlated with temperature. Temperature alone explains $40 \%$ of the variability in bacterial production during all seasons in the
Chesapeake Bay (Ducklow \& Shiah 1993). In the Delaware Estuary, the dependence of growth rate on temperature was particularly evident during cold months $\left(<12{ }^{\circ} \mathrm{C}\right)$, but once the water warmed above $12^{\circ} \mathrm{C}$ growth rate became independent of temperature. It appears that the colder water suppressed bacterial growth, even during the spring phytoplankton bloom. A lag between bacterial activity and the spring phytoplankton bloom is not unique to the Delaware Estuary. This has also been observed in the Baltic Sea where substrate supply was probably not limiting bacterial growth because concentrations of phytoplankton exudates were high during the bloom (Larsson \& Hagström 1982). Likewise, concentrations of dissolved primary amines were high during the Delaware Estuary bloom in 1987 and 1988 (this study) and dissolved combined and free amino acids were high during the 1985 bloom (Coffin \& Sharp 1987). Degradation of organic matter was low during a bloom in Newfoundland (Canada) because of the cold water (Pomeroy et al. 1991).

Temperature affected bacterial growth rate and production the most in the middle estuary and the least in the lower estuary. In a detailed regression analysis of published data, White et al. (1991) found that temperature had a greater impact on bacterial production and bacterial growth rates in marine than in freshwater environments. To explain this, they pointed out that inputs of labile DOM from autochthonous sources are relatively higher in marine than in freshwaters. This may partly explain why temperature had the largest impact in the middle estuary where phytoplankton biomass and production were highest during the spring bloom (surface water $<12^{\circ} \mathrm{C}$ ). Production of labile DOM is probably very high during spring blooms, which appears to make bacteria more sensitive to temperature. This interrelationship between temperature effects and DOM supply (and probably grazing) is also suggested by the lack of a temperature effect on growth rate in the lower estuary and throughout the estuary during warmer months $\left(>12^{\circ} \mathrm{C}\right)$. The relationship between temperature and bacterial parameters in the upper estuary was probably influenced by the effect of temperature on the input of allochthonous organic matter and nutrients from the entire watershed, such as river discharge, rather than a biochemical response alone

The supply rate of DOM alone can control the growth of bacteria and set limits on the standing stocks of bacteria in the system (Wright \& Coffin 1984. Kirchman 1990). The effect of DOM supply is implied by the high correlation between bacterial production and phytoplankton production and between bacterial abundance and phytoplankton production in the middle and lower estuary. The response of bacteria to 
changes in phytoplankton production is smaller in the upper estuary where allochthonous sources of DOM are probably important. Allochthonous inputs of organic carbon may also account for the disruption of bacterial and phytoplankton relationships in the Rhône River plume, France (Kirchman et al. 1989), the tidal Hudson River (Findlay et al. 1991), and the upper St. Lawrence Estuary (Painchaud \& Therriault 1989).

Not all of the variance in bacterial production could be explained by the measured parameters (particularly phytoplankton production and temperature), indicating that there are other important factors. Grazing is of course important (Wright \& Coffin 1984), and its effect on bacterial dynamics has been observed in several published studies. For example, Psenner \& Sommaruga (1992) found a high correlation between bacterial biomass and heterotrophic flagellate abundance before and after a cyanobacterial bloom in a lake. These authors suggested that control of bacteria switched from grazing to substrate control and then back to grazer control, all within weeks. Coffin \& Sharp (1987) implicated grazing by protists as limiting bacterial production in the Delaware Estuary, especially in the lower region. Likewise, our multivariate regression analysis suggests that factors other than phytoplankton production and temperature are most important in predicting bacterial production in the lower estuary.

One problem with relying on correlations to examine the impact of grazers on bacterial parameters is that, in addition to removing bacterial cells, grazing is also probably very important in producing DOM, thus fueling bacterial growth. In fact, this DOM production probably varies independently of phytoplankton production, which would account for the variability in bacterial numbers and growth rates seemingly independent of phytoplankton during the warmer months in the Delaware Estuary.

\section{Net heterotrophy versus autotrophy}

Microbial ecologists often use the ratio of heterotrophic bacterial production to phytoplankton production as an indicator of carbon flow through the microbial food chain. In the Delaware Estuary, individual measurements of the bacterial to primary production ratio were at times in excess of 5 (Coffin \& Sharp 1987 , this study). However, these values only reveal the instantaneous relationship between bacteria and phytoplankton, and do not reflect the system-wide trophic status for the water column. As emphasized by Coffin \& Sharp (1987) previously for the Delaware and by Scavia et al. (1986) in Lake Michigan, it is important to look at the ratio of bacterial to phytoplankton produc- tion averaged over larger space and time scales, i.e. not the average of ratios. This approach smoothes out the effects of uncoupling between phytoplankton production and substrate supply and any variability in bacterial parameters due to diel and mesoscale temporal cycling (Newell et al. 1988) which cause variation in the ratio of bacterial to phytoplankton production.

When the 3 yr averages for both bacterial and phytoplankton production are used the ratio was 0.25 and 0.40 during our study, based on Leu and TdR methods respectively. Assuming a $50 \%$ growth efficiency, these ratios imply that bacteria consumed between 50 to $80 \%$ of phytoplankton production over the entire estuary. These percentages are much higher than previously reported for the Delaware Estuary in 1985 (23\% of phytoplankton production; Coffin \& Sharp 1987), regardless of which measure of bacterial production is used or whether fall and winter months are included. The discrepancy is simple to explain: Coffin \& Sharp (1987) integrated over a $7 \mathrm{~m}$ water column whereas we integrated over $13 \mathrm{~m}$ water column. In any case, the average of the different bacterial production methods gives $65 \%$ (using a $13 \mathrm{~m}$ water column), which agrees with the grand average (60\%) reported by Cole et al. (1988).

In the upper estuary heterotrophy dominates the water column biology as bacterial respiration exceeds phytoplankton production by $40 \%$ (i.e. the ratio of bacterial to primary production equaled 1.4 ) when a $50 \%$ growth efficiency is assumed. Although it is possible for bacterial production or even total secondary production to exceed primary production because of recycling of organic matter between trophic levels and feedback of DOM to bacteria prior to oxidation, total respiration cannot exceed autotrophic inputs (Strayer 1988). For the water column to be autotrophic the mean bacteria growth efficiency would have to be $>70 \%$ which is unlikely. Also, even if such a high efficiency is assumed, the retentiveness would have to approach $100 \%$ which is also unlikely considering the large fluvial export from the upper estuary.

When bacterial production exceeds phytoplankton production allochthonous carbon must be supporting bacterial production. Concentrations of particulate (POC) (Cifuentes et al. 1988) and dissolved organic carbon (DOC) (>200 $\mu \mathrm{M}_{i}$ Lebo et al. 1990) are both high in the upper estuary. Wastewater treatment and effluents from cities (Trenton, NJ, Philadelphia, PA, and Wilmington, DE) are obvious sources of organic matter at the beginning of the salinity gradient (Albert 1988). Other sources could include surface runoff and export from salt marshes. A large fraction of estuarine bacterial growth can be supported by recalcitrant DOC, such as terrestrially-derived humic acids (Moran \& Hodson 1990), and vascular plant detritus (Moran \& 
Hodson 1989). During spring in the upper Delaware Estuary, POC is isotopically deplete in ${ }^{13} \mathrm{C}$ indicating a large terrestrial input (Cifuentes et al. 1988).

Few studies have examined net heterotrophy, due to bacterioplankton production alone, in temperate eutrophic systems. Heterotrophic activity by bacteria is greater than phytoplankton production by 4 -fold in the tidal Hudson River, which was corroborated by $\mathrm{O}_{2}$ consumption (Findlay et al. 1991). Similarly, in the upper region of the Delaware estuary there is an $\mathrm{O}_{2}$ deficit (Sharp et al. 1982) which cannot be accounted for by benthic $\mathrm{O}_{2}$ consumption alone (Seitzinger 1988).

\section{Inter-annual variability in phytoplankton and bacterial production}

Like cross-ecosystem comparisons, bacteria and phytoplankton appear to covary over the years, even if they do not covary tightly within a year during changes in seasons. One caveat for our inter-annual comparison is that we compared production estimates from warm months only. But temperature did not vary substantially during these years (Fig. 2A), and so any temperature effects on bacterial production were probably similar during 1985-1990. So the key to understanding what controls the inter-annual variation in bacteria is to understand the variation in primary production. Unfortunately, it is not clear what drives the inter-annual variation in phytoplankton.

As already mentioned, seasonal changes in primary production are largely determined by light and to lesser extent by nutrients (Pennock \& Sharp 1986), suggesting that we should first examine inter-annual variation in light. But, there are no apparent differences in stratification, in light attenuation, or in total irradiance during 1985-1990. In a more extensive study, Pennock \& Sharp (1986) were unable to suggest a mechanism to explain the inter-annual variation in primary production in the Delaware. Perhaps it is important to note that the 3 regions of the estuary all showed the same inter-annual variation. Thus, whatever drives this inter-annual variation must affect directly or indirectly the entire estuary.

Phytoplankton and bacterial production varied $>3$ fold from 1985 to 1990 , but the ratio of bacterial to primary production varied little, especially compared to methodological uncertainties and within-year variation. This suggests that the flux of DOM through bacteria and the fraction of primary production processed by bacteria is relatively constant when averaged over a year. It is also remarkable that this fraction ( $60 \%$ of primary production), which has been observed in crossecosystem studies (Cole et al. 1988, Ducklow \& Carlson 1992), appears to be relatively constant at the ecosys- tem level. It is still unclear how the fraction of primary production processed by bacteria can be so constant and why it is apparently set at $60 \%$.

Acknowledgements. We thank J. Sharp for access to the large data base on the Delaware estuary and $R$. Keil and $M$. Montgomery for technical assistance. This research was supported by NOAA Sea Grant 86AA-D-SG040 and NSF 8614170 .

\section{LITERATURE CITED}

Albert, R. C. (1988). The historical context of water quality management for the Delaware Estuary. Estuaries 11: 99-107

Bevington, P. R. (1969). Data reduction and error analysis for the physical sciences. McGraw Hill, New York

Biggs, R. B., Sharp, J. H., Church, T. M., Tramontano, J. M. (1983). Optical properties, suspended sediments, and chemistry associated with the turbidity maxima of the Delaware Estuary. Can. J. Fish. Aquat. Sci. 40: 172-179

Billen, G., Servais, P., Becquevort, S. (1990). Dynamics of bacterioplankton in oligotrophic and eutrophic aquatic environments: bottom-up or top-down control? Hydrobiol. 207: $37-42$

Bird, D. F., Kalff, J. (1984). Empirical relationships between bacterial abundance and chlorophyll concentration in fresh and marine waters. Can. J. Fish. Aquat. Sci. 41: $1015-1023$

Chin-Leo, G., Kirchman, D. L. (1988). Estimating bacterial production in marine waters from the simultaneous incorporation of thymidine and leucine. Appl. environ. Microbiol. 54: 1934-1939

Cifuentes, L. A., Sharp, J H., Fogel, M. L. (1988). Stable carbon and nitrogen isotope biogeochemistry in the Delaware estuary. Limnol. Oceanogr. 33: 1102-1115

Coffin, R. B., Sharp, J. H. (1987). Microbial trophodynamics in the Delaware Estuary. Mar. Ecol. Prog. Ser. 41: 253-266

Cole, J. J., Findlay, S., Pace, M. L. (1988). Bacterial production in fresh and saltwater ecosystems: a cross-system overview. Mar. Ecol. Prog. Ser. 43: 1-10

Ducklow, H. W., Shiah, F.-K. (1993). Bacterial production in estuaries In: Ford, T. G. (ed.) Aquatic microbiology: an ecological approach. Blackwell Scientific Publications, Boston, p. 261-287

Ducklow, H. W., Kirchman, D. L., Quinby, H. L., Carlson, C. A., Dam, H. G. (1993). Bacterioplankton carbon cycling during the spring bloom in the eastern North Atlantic Ocean. Deep Sea Res. II 40: 245-263

Ducklow, H. W. Carlson, C. A. (1992). Oceanic bacterial production. Adv. microb. Ecol. 12: 113-181

Ducklow, H. W., Kirchman, D. L. (1983). Bacterial dynamics and distribution during a spring diatom bloom in the Hudson River plume. USA. J. Plankton Res. 5: 333-355

Ducklow, H. W., Kirchman, D. L., Quinby, H. L. (1992). Determination of bacterioplankton growth rates during the North Atlantic spring phytoplankton bloom. Microb. Ecol. 24: 125-144

Findlay, S., Pace, M. L., Lints, D., Cole, J. J., Caraco, N. F., Peierls, B. (1991). Weak coupling of bacterial and algal production in a heterotrophic ecosystem: the Hudson River estuary. Limnol. Oceanogr. 36: 268-278

Fuhrman, J. A., Azam, F. (1982). Thymidine incorporation as a measure of heterotrophic bacterioplankton production in marine surface waters: evaluation and field results. Mar. Biol 66: 109-120 
Fuhrman, J. A., Ammerman, J. W., Azam, F. (1980). Bacterioplankton in the coastal euphotic zone: distribution, activity and possible relationships with phytoplankton. Mar. Biol. 60: 201-207

Hobbie, J. E., Daley, R. J., Jasper, S. (1977). Use of Nuclepore filters for counting bacteria by fluorescence microscopy. Appl. environ. Microbiol. 33: 1225-1228

Hoch, M. P. (1992). Ammonium uptake by heterotrophic marine bacteria: environmental control and nitrogen isotope biogeochemistry. Ph.D. dissertation, University of Delaware, Newark

Kirchman, D. L. (1990). Limitation of bacterial growth by dissolved organic matter in the subarctic Pacific. Mar. Ecol. Prog. Ser. 62: 47-54

Kirchman, D. L., Hoch, M. P. (1988). Bacterial production in the Delaware Bay estuary estimated from thymidine and leucine incorporation rates. Mar. Ecol. Prog. Ser. 45: $169-178$

Kirchman, D. L., Ducklow, H. W., Mitchell, R. (1982). Estimates of bacterial growth from changes in uptake rates and biomass Appl environ. Microbiol. 44: $1296-1307$

Kirchman, D. L., K'nees, E., Hodson, R. E. (1985). Leucine incorporation and its potential as a measure of protein synthesis by bacteria in natural aquatic systems. Appl. environ. Microbiol. 49: 599-607

Kirchman, D. L., Soto, Y., Van Wambeck, F., Bianchi, M. (1989). Bacterial production in the Rhône River plume: effect of mixing on relationships among microbial assemblages. Mar. Ecol. Prog. Ser. 53: 267-275

Larsson, U., Hagström, A. (1982). Fractionated phytoplankton primary production, exudate release and bacterial production in a Baltic eutrophication gradient. Mar. Biol. 67 : $57-70$

Lebo, M. E., Cifuentes, L. A., Fogel, M. L., Hoch, M. P., Keil, R. G., Kirchman, D. L., Ludlam, J. M., Pennock, J. R., Sharp, J. H., Spicer, P. T., Velinsky, D. J. (1990). DEL-SG06-90 Oceanographic data report No. 7: Data from the Delaware estuary SCENIC cruises. Univ. of Delaware Sea Grant, Newark

Lee, S., Fuhrman, J. A. (1987). Relationships between biovolume and biomass of naturally derived marine bacterioplankton. Appl. environ. Microbiol. 53: 1298-1303

Moran, M. A., Hodson, R. E. (1989). Bacterial secondary production on vascular plant detritus; relationships to detritus composition and degradation rate. Appl. environ. Microbiol 55: 2178-2189

Moran, M. A., Hodson, R. E. (1990). Bacterial production on humic and nonhumic components of dissolved organic carbon. Limnol. Oceanogr. 35: 1744-1756

Morris, D. P., Lewis, W. M. (1992). Nutrient limitation of bacterioplankton growth in Lake Dillon, CO. Limnol. Oceanogr. 37: 1179-1192

Nagata, T (1987). Production rate of planktonic bacteria in the north basin of Lake Biwa, Japan. Appl. environ. Microbiol. 53: 2872-2882

Newell, S. Y., Fallon, R. D., Sherr, B. F., Sherr, E. B. (1988). Mesoscale temporal variation in bacterial standing crop. percent active cells, productivity and output in a saltmarch tidal river. Verh. int. Verein Linmol. 23: 1839-1845

Painchaud, J., Therriault, J.-C. (1989). Relationships between bacteria, phytoplankton and particular organic carbon in the upper St. Lawrence estuary. Mar. Ecol. Prog. Ser. 56: $301-311$

Parsons, T. R., Maita, Y., Lalli, C. M. (1984). A manual of chemical and biological methods for seawater analysis Pergammon Press, Oxford

Pennock, J. R. (1985). Chlorophyll distribution in the Delaware Estuary: regulation by light-limitation. Estuar coast. Shelf Sci. 21. 711-725

Pennock, J. R., Sharp, J. H. (1986). Phytoplankton production in the Delaware Estuary: temporal and spatial variability Mar. Ecol. Prog. Ser. 34: 143-155

Pomeroy, L. R., Wiebe, W. J., Deibel, D., Thompson, R. J., Rowe, G. T., Pakulski, J. D. (1991). Bacterial responses to temperature and substrate concentration during the Newfoundland spring bloom. Mar. Ecol. Prog. Ser. 75: 143-159

Psenner, R., Sommaruga, R. (1992). Are rapid changes in bacterial biomass caused by shifts from top-down to bottomup control? Limnol. Oceanogr. 37: 1092-1100

Riemann, B., Bjornsen, P. K., Newell, S., Fallon, R. (1987). Calculation of cell production of coastal marine bacteria based on measured incorporation of $\left[{ }^{3} \mathrm{H}\right]$ thymidine. Limnol. Oceanogr. 32: 471-476

Scavia, D., Laird, G. A., Fahnenstiel, G. L. (1986). Production of planktonic bacteria in Lake Michigan. Limnol. Oceanogr. 31: 612-626

Seitzinger, S. P. (1988). Benthic nutrient cycling and oxygen consumption in the Delaware Estuary. In: Majumdar, S. K., Miller, E. W., Sage, L. E. (eds.) Ecology and restoration of the Delaware River Basin. The Pennsylvania Academy of Science, Philadelphia, p. 132-147

Sharp, J. H., Culberson, C. H., Church, T M. (1982). The chemistry of the Delaware Estuary: general considerations. Limnol. Oceanogr. 27: 1015-1028

Sharp, J. H., Cifuentes, L. A., Pennock, J. R., Wong, K.-C. (1986). The influence of river variability on the circulation, chemistry, and microbiology of the Delaware Estuary. Estuaries 9: 261-269

Simon, M., Tilzer, M. M. (1987). Bacterial response to seasonal changes in primary production and phytoplankton biomass in Lake Constance. J. Plankton Res. 9: 535-552

Sokal, R., Rohlf, F. J. (1981). Biometry: the principles and practice of statistics in biological research, 2 nd edn. W. H. Freeman, San Francisco

Sprugel, D. G. (1983). Correcting for bias in log-transformed allometric equations. Ecology 64: 209-210

Strayer, D. (1988). On the limits to secondary production. Limnol. Oceanogr. 33: 1217-1220

Toolan, T., Wehr, J. D., Findlay, S. (1991). Inorganic phosphorus stimulation of bacterioplankton production in a mesoeutrophic lake. Appl. environ. Microbiol. 57: 2074-2078

Wheeler, P. A., Kirchman, D. L. (1986). Utilization of inorganic and organic nitrogen by bacteria in marine systems. Limnol. Oceanogr. 31: 998-1009

White, P. A., Kalff, J., Rasmussen, J. B., Gasol, J. M. (1991). The effect of temperature and algal biomass on bacterial production and specific growth rate in freshwater and marine habitats. Microbiol. Ecol. 21. 99-118

Wright, R. T. (1988). A model for short-term control of the bacterioplankton by substrate and grazing. Hydrobiol. 159: 111-117

Wright, R. T., Coffin, R. B. (1984). Measuring microzooplankton grazing on planktonic marine bacteria by its impact on bacterial production. Microbiol. Ecol. 10: 137-149

Wright, R. T., Coffin, R. B., Lebo, M. E. (1987). Dynamics of planktonic bacteria and heterotrophic microflagellates in the Parker Estuary, northern Massachusetts. Cont. Shelf Res. 7: $1383-1397$ 


\section{Re: P. J. Williams, J. A. Brown}

Mar. Ecol. Prog. Ser. 88: 185-193 (1992)

- The above article incorrectly reports mean and maximum escape speeds of larval winter flounder. The actual speeds are greater than reported by a factor of 2 . For example, if a speed of $4 \mathrm{~cm} \mathrm{~s}^{-1}$ is listed in the article, the actual speed is $8 \mathrm{~cm} \mathrm{~s}^{-1}$. Figs. 1, 2, 4 \& 5 are affected by this change. The regressions provided in Table 2 for calculating mean and maximum speed should read:

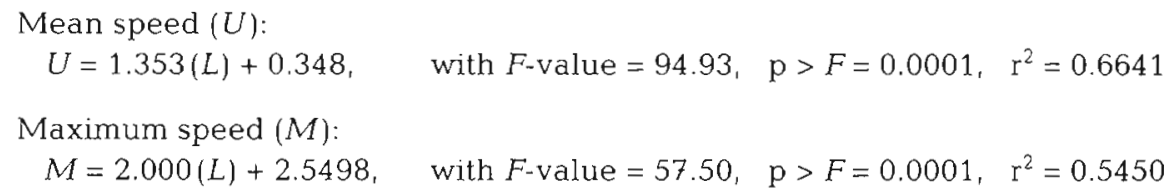

Both speeds are in $\mathrm{cm} \mathrm{s}^{-t}$, and lengths are total lengths in $\mathrm{mm}$.

One of the main conclusions of the article was that flounder larvae exhibited escape speed parameters lower than values published for other species of larval fish (paragraph 3 of 'Discussion'). We now feel that this is not the case, and we report that flounder larvae perform at similar levels as had previously been reported for other species of larval fish. The other conclusions of the article, including the description of the escape response and the relationship between length and escape performance, remain qualitatively unchanged. The authors apologize for the error, and regret any inconvenience the incorrect values may have caused. Anyone wishing further clarification may contact P. J. Williams at the address below.

Dept of Fisheries and Oceans, PO Box 5030, Moncton,

New Brunswick, Canada E1C 9B6

\section{Re: M. P. Hoch, D. L. Kirchman}

Mar. Ecol. Prog. Ser. 98: 283-295 (1993)

- Table 2 , on p. 288 , contained 3 misprinted values. The corrected table appears below.

Table 2. Summary of biological properties for the upper, middle, and lower regions of the Delaware Estuary, 1986 to 1988 . The ratio of bacterial production to primary production is given as Bprod:Pprod

\begin{tabular}{|c|c|c|c|c|c|c|}
\hline & \multirow{2}{*}{$\begin{array}{c}\text { Chl } a \\
\left(\mu \mathrm{g} \mathrm{l}^{-1}\right)\end{array}$} & \multirow{2}{*}{ 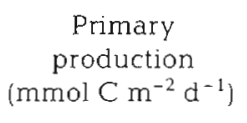 } & \multicolumn{3}{|c|}{$\longrightarrow$ Bacteria -} & \multirow[t]{2}{*}{ Bprod:Pprod } \\
\hline & & & $\begin{array}{c}\text { Abundance } \\
\left(10^{6} \mathrm{ml}^{-1}\right)\end{array}$ & $\begin{array}{l}\text { Growth } \\
\text { rate }\left(d^{-1}\right)\end{array}$ & 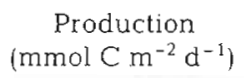 & \\
\hline \multicolumn{7}{|l|}{ Upper region } \\
\hline $\begin{array}{l}\text { Mean } \pm \mathrm{SD} \\
\text { Max min }\end{array}$ & $\begin{array}{l}11.2 \pm 10.3 \\
700.11\end{array}$ & $19.0 \pm 19.9$ & $\begin{array}{l}3.0 \pm 2.0 \\
(127078)\end{array}$ & $0.336 \pm 0.216$ & $27.3 \pm 26.2$ & $4.32 \pm 6.32$ \\
\hline (toran & 107 & 103 & 89 & 88 & 89 & 88 \\
\hline \multicolumn{7}{|l|}{ Middle region } \\
\hline $\begin{array}{l}\text { Mean } \pm \mathrm{SD} \\
(\mathrm{Max}, \min )\end{array}$ & $\begin{array}{l}15.0 \pm 15.6 \\
(81.7 .2 .6)\end{array}$ & $\begin{array}{l}61.4 \pm 66.3 \\
(422,0.93)\end{array}$ & $\begin{array}{c}3.3 \pm 2.1 \\
(9.1,0.93)\end{array}$ & $\begin{array}{l}0.240 \pm 0.144 \\
(0.720,0.024)\end{array}$ & $\begin{array}{l}23.3 \pm 21.1 \\
(88.4+1.20)\end{array}$ & $\begin{array}{l}0.65 \pm 0.73 \\
(5.24,0.06)\end{array}$ \\
\hline n & 89 & 87 & 73 & 70 & 72 & 72 \\
\hline \multicolumn{7}{|l|}{ Lower region } \\
\hline $\begin{array}{l}\text { Mean } \pm S D \\
\text { (Max min) }\end{array}$ & $\begin{array}{l}10.8 \pm 9.0 \\
(56.31 .1)\end{array}$ & $\begin{array}{c}75.1 \pm 101.1 \\
(735.1 .3)\end{array}$ & $\begin{array}{c}3.7 \pm 2.3 \\
(11.1,0.65)\end{array}$ & $\begin{array}{l}0.216 \pm 0.168 \\
(0.9840 .024)\end{array}$ & $\begin{array}{l}24.0 \pm 25.1 \\
(138.1 .11)\end{array}$ & $\begin{array}{l}0.51 \pm 0.54 \\
(3.48,0.05)\end{array}$ \\
\hline$n$ & 108 & 103 & 90 & 85 & 82 & 77 \\
\hline
\end{tabular}

